\title{
The Diversity of Cyanobacterial Genomes with Respect to Ribosomal RNA Cistrons
}

\author{
By J. M. NICHOLS, I. J. FOULDS, D. H. CROUCH AND N. G. CARR* \\ Department of Biochemistry, University of Liverpool, P.O. Box 147, Liverpool L69 3BX, U.K.
}

(Received 5 March 1982)

\begin{abstract}
The ribosomal RNAs were isolated from cyanobacteria (Anacystis nidulans, Anabaena cylindrica, Anabaena CA and Nostoc MAC) and labelled in vitro with $\left[\gamma^{-32} \mathrm{P}\right] \mathrm{ATP}$ and polynucleotide kinase. DNA from the corresponding species was isolated, digested with EcoRI or HindIII, and resolved on agarose gels. In situ hybridization was used to measure the number and location of the $16 \mathrm{~S}$ and $23 \mathrm{~S}$ ribosomal RNA genes. The comparative results are discussed in relation to the known genome size of these species and to their RNA content per cell.
\end{abstract}

\section{INTRODUCTION}

The cyanobacteria are the largest, most diverse and most widely distributed group of photosynthetic prokaryotes (Stanier \& Cohen-Bazire, 1977). They display many morphological forms, ranging from unicellular species reproducing by binary fission in only one plane, through unicellular species dividing by multiple fission, filamentous species without and with heterocysts dividing in a single phase, to branching filamentous forms. Herdman et al. (1979) have suggested that there is a correlation between genome size, measured by renaturation kinetics, and morphological complexity: strains which exhibit a high degree of morphological differentiation almost invariably possess genomes which are larger than those strains with a simple morphological form. The distribution of genome size was discontinuous, dividing into four discrete groups, the mean values for each group corresponding closely to those which would be obtained by a process of genome evolution involving a series of fusions of a smaller ancestral genome.

The diversity in size of the genomes of cyanobacteria may be reflected in the number of rRNA genes encoded by the DNA. In Escherichia coli the rRNA genes are organized in seven or eight clusters, each of which contains $16 \mathrm{~S}, 23 \mathrm{~S}$ and $5 \mathrm{~S}$ rRNA and a number of tRNA genes (Kiss et al., 1977; Kenerley et al., 1977). The organization is basically similar in Bacillus subtilis (Zingales \& Colli, 1977), there probably being up to 10 copies of the rRNA operon (Potter et al., 1977). In $E$. coli it has been known for some time that the rRNAs are transcribed polycistronically in the order 5'-16S, 23S, 5S-3' (Hamkalo \& Miller, 1973; Pace, 1973). Such an arrangement is probably also present in B. subtilis (Zingales \& Colli, 1977) and B. thuringiensis (Klier et al., 1979). By contrast, in Beneckea harveyi, a marine bacterium, the rRNA genes are linked, but in an order different to that in E. coli (Lamfrom et al., 1978). The rRNAs of the cyanobacteria, like those of other prokaryotes, have molecular weights of approximately $0.04 \times 10^{6}, 0.55 \times 10^{6}$ and $1.05-$ $1.11 \times 10^{6}$ (Pace, 1973; Loening, 1968; Dobson et al., 1974). Except for the determination of multiple (two) rRNA cistrons, linked in the order 16S-23S-5S, in Anacystis nidulans (Doolittle et al., 1979), nothing is known of the organization and number of rRNA genes in other species of cyanobacteria. This communication presents evidence for the diversity of cyanobacteria with respect to the multiplicity of rRNA cistrons determined, in four species, by Southern hybridization (Southern, 1975) of in vitro labelled RNA on to restricted DNA. 


\section{METHODS}

Organisms and culture conditions. Anabaena CA (ATCC 33047) was grown at $39^{\circ} \mathrm{C}$ and $230 \mu \mathrm{E} \mathrm{m}^{-2} \mathrm{~s}^{-1}$ on BG11 medium (Rippka et al., 1979), modified by adding $75 \mathrm{mM}-\mathrm{NaCl}$ and $0.3 \mathrm{~g} \mathrm{HEPES} 1^{-1}$, and by increasing the concentration of $\mathrm{MgSO}_{4} \cdot 7 \mathrm{H}_{2} \mathrm{O}$ to $20 \mathrm{mM}$ and that of $\mathrm{CaCl}_{2} \cdot 2 \mathrm{H}_{2} \mathrm{O}$ to $3 \cdot 3 \mathrm{mM}$. Anabaena cylindrica (Culture Centre of Algae and Protozoa, Cambridge, U.K., no. 1403/2a) was grown at $29^{\circ} \mathrm{C}$ and $45 \mu \mathrm{E} \mathrm{m}^{-2} \mathrm{~s}^{-1}$ on the medium of Allen \& Arnon (1955) modified by the addition of $4 \mathrm{~mm}-\mathrm{NH}_{4} \mathrm{Cl}$. Anacystis nidulans (Culture Collection of Algae at the University of Texas, Austin, Texas UTEX 625) was grown at $30^{\circ} \mathrm{C}$ and $90 \mu \mathrm{E} \mathrm{m}^{-2} \mathrm{~s}^{-1}$ on Medium C (Kratz \& Myers, 1955) with the addition of $1 \mathrm{~g} \mathrm{NaHCO}_{3} \mathrm{l}^{-1}$. Nostoc MAC (known also as Nostoc sp., supplied by Dr A. J. Smith, Department of Biochemistry, University of Wales, Aberystwyth and now deposited with the Culture Collection of the Institut Pasteur, PCC 8009) was grown at $37^{\circ} \mathrm{C}$ and $70 \mu \mathrm{E} \mathrm{m}^{-2} \mathrm{~s}^{-1}$ on Medium C. All cultures were gassed with air $/ \mathrm{CO}_{2}(95: 5, \mathrm{v} / \mathrm{v})$.

Preparation of DNA. Organisms were harvested by centrifugation during exponential growth, washed in $0 \cdot 15 \mathrm{M}$ $\mathrm{NaCl}, 0 \cdot 1 \mathrm{M}$-EDTA, pH 8, and resuspended to $1 \mathrm{~g}$ wet wt cells per $10 \mathrm{ml}$ in the above buffer. The suspension was incubated with $1 \mathrm{mg}$ lysozyme $\mathrm{ml}^{-1}$ for $2 \mathrm{~h}$ at $37^{\circ} \mathrm{C}$. DNA was subsequently extracted by the method of Marmur (1961) and finally resuspended in $10 \mathrm{~mm}$-Tris/ $\mathrm{HCl} \mathrm{pH} 8$, containing $1 \mathrm{~mm}$-EDTA and stored at $4{ }^{\circ} \mathrm{C}$, over chloroform.

Isolation and radioactive labelling of $R N A$. All organisms were harvested during exponential growth by centrifugation at $4000 \mathrm{~g}$ for $20 \mathrm{~min}$. RNA was isolated from Anabaena cylindrica after washing and resuspension of the cells in $20 \mathrm{mM}$-Tris/ $\mathrm{HCl}$, $\mathrm{pH} 7.8$ containing $5 \mathrm{mM}-\mathrm{MgCl}_{2}$. The cells were broken at $84 \mathrm{MPa}\left(12000 \mathrm{lbf}^{-2}\right)$ in a French pressure cell and collected into $20 \%(\mathrm{w} / \mathrm{v}) \mathrm{SDS}$ to a final concentration of $1 \%$ SDS. The RNA was isolated by three extractions with an equal volume of a mixture of water-saturated phenol/cresol/hydroxyquinoline $(50 \mathrm{~g}: 7 \mathrm{ml}: 0.05 \mathrm{~g})$ at $4{ }^{\circ} \mathrm{C}$. To the final supernatant was added 0.1 vol. $2 \mathrm{M}$-sodium acetate, pH 6.0 and 2 vol. absolute ethanol. The precipitated RNA was collected by centrifugation and washed in $0 \cdot 15 \mathrm{M}$-sodium acetate, pH 6.0, containing $0.5 \%$ SDS; the RNA was reprecipitated with ethanol, then finally resuspended in $0.15 \mathrm{M}$ sodium acetate $\mathrm{pH} 6.0$ and stored at $-70^{\circ} \mathrm{C} .16 \mathrm{~S}$ and $23 \mathrm{~S}$ rRNAs were prepared by precipitation with $1.5 \mathrm{M}-\mathrm{NaCl}$ for $10 \mathrm{~h}$ at $4{ }^{\circ} \mathrm{C}$ and each rRNA purified by electrophoresis on $2.8 \%$ polyacrylamide gels (Loening, 1968). The bands were located by UV shadowing (Hassur \& Whitlock, 1974); the RNA was extracted from the gels as described by Maxam \& Gilbert (1977) and further purified by passing through columns of Whatman CF-11 cellulose (Franklin, 1966).

Ribosomal RNAs were purified from Anabaena CA, Anacystis nidulans and Nostoc MAC by the isolation of ribosomes and subsequent dissociation into subunits. Organisms were harvested and washed with $10 \mathrm{~mm}$ Tris $/ \mathrm{HCl}, \mathrm{pH} 7 \cdot 6$, containing $100 \mathrm{~mm}-\mathrm{KCl}$ and $10 \mathrm{~mm}$-magnesium acetate (buffer A). After resuspension in a small volume of Buffer A and addition of RNAase-free DNAase (Millipore) to $2 \mu \mathrm{g} \mathrm{ml}^{-1}$, the cells were broken in a French Pressure cell at $84 \mathrm{MPa}$. Triton X-100 was added to a final concentration of $5 \%(\mathrm{v} / \mathrm{v})$ and the suspension incubated for $15 \mathrm{~min}$ at $4{ }^{\circ} \mathrm{C}$. Two centrifugations at $15000 \mathrm{~g}$ for $15 \mathrm{~min}$ removed cell debris and the supernatant was layered over equal volumes of $1 \mathrm{M}$-sucrose in buffer $\mathrm{A}$ and centrifuged at $165000 \mathrm{~g}$ for $2.5 \mathrm{~h}$. The resulting ribosomal pellets were resuspended in $10 \mathrm{~mm}-\mathrm{Tris} / \mathrm{HCl}, \mathrm{pH} 7 \cdot 6$, containing $100 \mathrm{mM}-\mathrm{KCl}$ and $0.1 \mathrm{mM}$-magnesium acetate (buffer B) and the dissociated ribosomal subunits fractionated on $36 \mathrm{ml} 7 \cdot 5-20 \%$ sucrose gradients in buffer $\mathrm{B}$ for $16 \mathrm{~h}$ at $5{ }^{\circ} \mathrm{C}$ and $70000 \mathrm{~g}$. The $30 \mathrm{~S}$ and $50 \mathrm{~S}$ subunits were separately recovered by adjusting peak fractions to $10 \mathrm{mM}$-magnesium acetate and adding polyethylene glycol to a final concentration of $10 \%(\mathrm{w} / \mathrm{v})$ (Expert-Bezancon et al., 1974). After standing on ice for $1 \mathrm{~h}$, the subunits were recovered by centrifugation at $15000 \mathrm{~g}$ for $20 \mathrm{~min}$ and resuspended in $50 \mathrm{~mm}$-Tris $/ \mathrm{HCl}, \mathrm{pH} 8.5$, containing $500 \mathrm{~mm}-\mathrm{KCl}, 10 \mathrm{mM}-\mathrm{EDTA}$ and $0.1 \mathrm{mM}$-magnesium acetate (buffer $\mathrm{C}$ ) and again fractionated on $7 \cdot 5-20 \%$ sucrose gradients in buffer $\mathrm{C}$ minus the EDTA. The $50 \mathrm{~S}$ and $30 \mathrm{~S}$ subunits were precipitated by the addition of magnesium acetate (final concentration, $10 \mathrm{~mm}$ ) and $1.5 \mathrm{vol}$. ethanol; the suspension was allowed to stand for $2 \mathrm{~h}$ at $4{ }^{\circ} \mathrm{C}$, and subunits were recovered by centrifugation at $18000 \mathrm{~g}$ for $20 \mathrm{~min}$.

The subunits were resuspended in $20 \mathrm{~mm}-\mathrm{Tris} / \mathrm{HCl}, \mathrm{pH} 7 \cdot 8$, containing $5 \mathrm{~mm}-\mathrm{MgCl}_{2}$, and the RNA isolated as described for Anabaena cylindrica. The RNA preparations were checked for purity by electrophoresis on $2 \cdot 8 \%$ polyacrylamide gels.

High specific activity in vitro-labelled $16 \mathrm{~S}$ and $23 \mathrm{~S}$ rRNAs were prepared by partial hydrolysis in $50 \mathrm{~mm}$ Tris/ $\mathrm{HCl}$, pH 9.5 , containing $0.1 \mathrm{~mm}$-spermidine $\left(95^{\circ} \mathrm{C}\right.$ for $\left.15 \mathrm{~min}\right)$ and $5^{\prime}$-end labelling by the method of Silberklang et al. (1979) with polynucleotide kinase (Boehringer-Mannheim) and 1.85 MBq [ $\gamma^{32}$ P]ATP (74 TBq mmol $^{-1}$; Amersham).

Hybridization of $r$ RAs to DNA. DNA (9-12 $\mu \mathrm{g})$ was digested in $100 \mu \mathrm{l}$ reaction volumes at $37^{\circ} \mathrm{C}$ for $16 \mathrm{~h}$, with either EcoRI (Boehringer-Mannheim) or HindIII (Bethesda Research Laboratories), each at 30-40 units $\mu \mathrm{g}^{-1}$. The incubation buffer for $E c o R I$ contained $100 \mathrm{mM}-\mathrm{Tris} / \mathrm{HCl}, \mathrm{pH} 7 \cdot 5,50 \mathrm{mM}-\mathrm{NaCl}$ and $10 \mathrm{mM}-\mathrm{MgCl}_{2}$, and that for

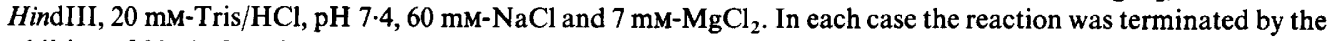
addition of $20 \mu \mathrm{l}$ of a mixture containing $0.2 \%(\mathrm{w} / \mathrm{v})$ agarose, $10 \%(\mathrm{v} / \mathrm{v})$ glycerol, $0.05 \%(\mathrm{w} / \mathrm{v})$ bromophenol blue

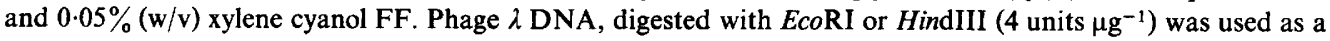
molecular weight marker. 
The digested cyanobacterial DNA and the $\lambda$ DNA marker were resolved on $0.7 \%$ agarose gels dissolved in either $50 \mathrm{~mm}$-Tris $/ \mathrm{HCl}, \mathrm{pH} 8.0$, containing $2 \mathrm{~mm}$-sodium acetate and $18 \mathrm{mM}-\mathrm{NaCl}$, or $160 \mathrm{~mm}$-Tris/acetate, $\mathrm{pH} 8 \cdot 0$, containing $8 \mathrm{~mm}$-EDTA, $80 \mathrm{~mm}$-sodium acetate and $80 \mathrm{~mm}-\mathrm{NaCl}$. Gels were run for $16-24 \mathrm{~h}$ at $100 \mathrm{~mA}$, at room temperature. The DNA fragments in the gels were denatured, neutralized and transferred to cellulose nitrate filters as described by Southern (1975). Filter strips, $1 \mathrm{~cm}$ wide, containing approximately $2 \mu \mathrm{g}$ DNA, were hybridized with up to $1 \mu \mathrm{g}$ of in vitro-labelled rRNAs (usually greater than $10^{6}$ c.p.m. $\mu \mathrm{g}^{-1}$ ) in $300 \mu 14 \times$ SSC $\left(0.6 \mathrm{M}-\mathrm{NaCl}, 0.06 \mathrm{M}\right.$-sodium citrate), $50 \%$ (v/v) formamide and $E$. coli tRNA $\left(60 \mu \mathrm{g} \mathrm{ml}^{-1}\right)$. The filters were sealed with Cling-film and hybridization carried out at $42^{\circ} \mathrm{C}$ for $16 \mathrm{~h}$. The strips were then washed twice for $1 \mathrm{~h}$ in $4 \times$ $\mathrm{SSC} / 50 \%(\mathrm{v} / \mathrm{v})$ formamide, at $42^{\circ} \mathrm{C}$, rinsed in $2 \times \mathrm{SSC}$, digested with pancreatic ribonuclease $\left(20 \mu \mathrm{g} \mathrm{ml}{ }^{-1}\right)$ in $2 \times$ SSC at $20^{\circ} \mathrm{C}$ for $30 \mathrm{~min}$, then finally washed three times for $10 \mathrm{~min}$ in $2 \times \mathrm{SSC}$. After air-drying, the filter-strips were mounted on a glass plate and the radioactive bands detected by autoradiography using Ilford Red Seal 100 FW X-ray film.

\section{RESULTS}

Anacystis nidulans

The hybridization of Anacystis nidulans rRNAs to A. nidulans DNA digested with EcoRI is shown in Fig. 1(a) (lanes 2 and 4). 16S rRNA gave hybridization signals with fragments of approximately $15 \mathrm{MDal}$ and $12 \mathrm{MDal}$ and with a double band of 5.2/5.1 MDal, whereas $23 \mathrm{~S}$ rRNA only hybridized with the 15 and 12 MDal fragments. The 23S rRNA and 16S rRNA genes must, therefore, be closely linked since, except for the 5.2/5.1 MDal fragments, they hybridized to identical fragments of DNA. The hybridization of only 16S rRNA to the smaller 5.2/5.1 MDal fragments showed that there must be an EcoRI site within the $16 \mathrm{~S}$ cistron. A possible explanation for this hybridization pattern is given in Fig. 1(b). The approximately equal intensity of the $12 \mathrm{MDal}$ and $15 \mathrm{MDal}$ bands (as measured by a Zeiss scanning densitometer) suggested an equal number of cistrons on each fragment; the simplest explanation for this would be that there are two rRNA cistrons in $A$. nidulans, as also suggested by Doolittle et al. (1979). If there were more than two rRNA cistrons, flanking sequences at some distance (as much as $18 \mathrm{~kb}=12 \mathrm{MDal}$ ) must have been conserved. The 12 and $15 \mathrm{MDal}$ fragments were created because of the heterogeneity in the flanking sequence of the 23S rRNA cistron, the EcoRI site therefore being at a different position. The 5.2/5.1 MDal double band could be explained in the same way. The rRNA cistrons must be at least $25 \mathrm{~kb}$ apart (equivalent to 16.7 MDal of double-stranded DNA). The size of the spacer DNA between the 16S and 23S rRNA cistrons cannot be determined from these results. The analogous spacer in $E$. coli is quite small, being approximately $0.2 \mathrm{MDal}$ (Lund et al., 1976). The exact position of the EcoRI site within the 16S rRNA cistron cannot be determined, but it is assumed to be near the centre, since each of the smaller $5 \cdot 2 / 5 \cdot 1 \mathrm{MDal}$ fragments were of approximately equal intensity to each of the two larger fragments.

When $A$. nidulans DNA was digested with HindIII, the $16 \mathrm{~S}$ rRNA hybridized to a $2.8 \mathrm{MDal}$ fragment, while $23 \mathrm{~S}$ rRNA hybridized to five fragments of 5.7, 2.3, 0.9, 0.7 and $0.5 \mathrm{MDal}$ (Fig. $1 a$, lanes 1 and 3 ). Since the $16 \mathrm{~S}$ and $23 \mathrm{~S}$ rRNA hybridized to no common fragment, a HindIII site must be present in the spacer region between the $16 \mathrm{~S}$ and $23 \mathrm{~S}$ cistrons. A tentative map of the approximate HindIII sites in relation to the $16 \mathrm{~S}$ and 23S RNA cistrons is given in Fig. 1(b), again assuming that there are two rRNA cistrons. The 5.7 and 2.3 MDal fragments hybridizing to $23 \mathrm{~S}$ rRNA were of equal intensity, but no comparison can be made with the three small fragments, since the bands were very diffuse. Therefore, it is not possible to determine the exact HindIII sites within the 23S rRNA cistron.

\section{Anabaena $C A$}

Both 16S rRNA and 23S rRNA from Anabaena CA gave hybridization signals with DNA fragments of $7 \cdot 8,5 \cdot 3,4 \cdot 2,3.0$ and $2 \cdot 4 \mathrm{MDal}$ after digestion of Anabaena CA DNA with EcoRI (Fig. 2a). There was also evidence of two faint hybridization bands of low molecular weight for the 23S rRNA, but possibly not for the $16 \mathrm{~S}$ rRNA. These results show that the $16 \mathrm{~S}$ and $23 \mathrm{~S}$ rRNAs are closely linked and that there are a minimum of five rRNA cistrons. Since the 3.0 and 2.4 MDal fragments are smaller than the length of DNA needed to code for the 16S rRNA plus 


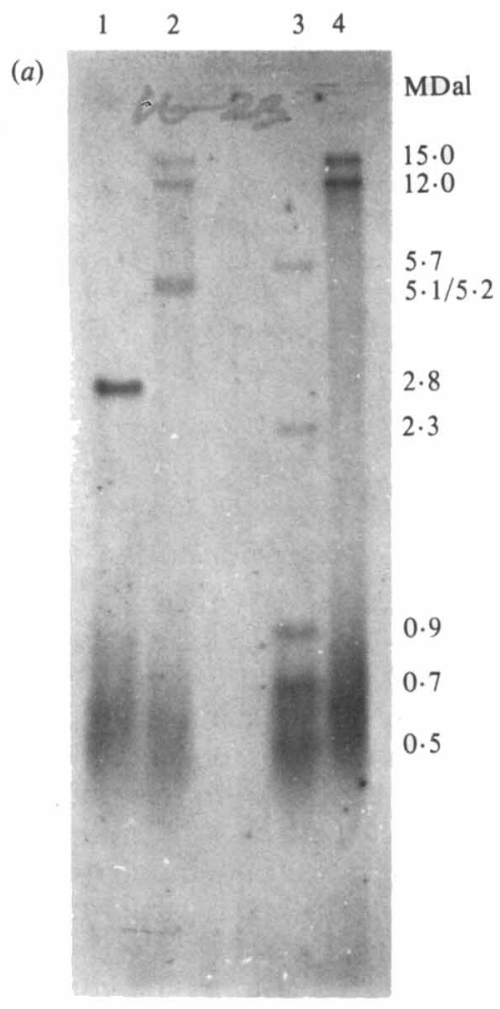

(b)

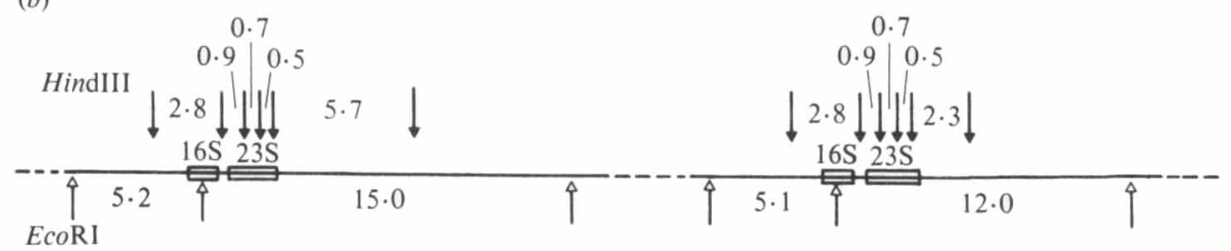

Fig. 1. (a) Hybridization of ${ }^{32}$ P-labelled Anacystis nidulans rRNAs to $A$. nidulans DNA. The DNA was digested with HindIII (lanes 1 and 3) or EcoRI (lanes 2 and 4), resolved on a $0.7 \%$ agarose gel and following transfer to nitrocellulose filter strips was hybridized with $16 \mathrm{~S}$ rRNA (106 c.p.m., $200 \mathrm{ng}$; lanes 1 and 2$)$ or $23 \mathrm{~S}$ rRNA $\left(10^{6}\right.$ c.p.m., $100 \mathrm{ng}$; lanes 3 and 4). The sizes of the DNA fragments are given in MDal.

(b) Diagram showing the arrangement of the $A$. nidulans rRNA cistrons with respect to the tentative EcoRI and HindIII restriction sites. The numbers indicate the sizes of the DNA fragments (MDal).

23S rRNA (minimum of 3.32 MDal) it follows that there must be one (or two) EcoRI sites within two rRNA cistrons. This points to minor differences in the rRNA cistrons. The two faint hybridization signals with fragments of low molecular weight for the 23S rRNA could account for the small portions of the $23 \mathrm{~S}$ rRNA cistron, produced by one EcoRI site within two 23S rRNA cistrons.

Digestion of Anabaena CA with HindIII also gave multiple hybridization signals. Four fragments of molecular size 2.8,2.3, 1.9 and 1.6 MDal were common to both 23S and 16S rRNA (Fig. $2 b$ ). 23S rRNA also hybridized to a fragment of $8 \mathrm{MDal}$, but $16 \mathrm{~S}$ rRNA only gave a very faint signal with this fragment. Since all the fragments, except for that at $8 \mathrm{MDal}$, are below the minimum cistron size for $16 \mathrm{~S}$ and $23 \mathrm{~S}$ rRNA, one would expect to see smaller, but non-identical 


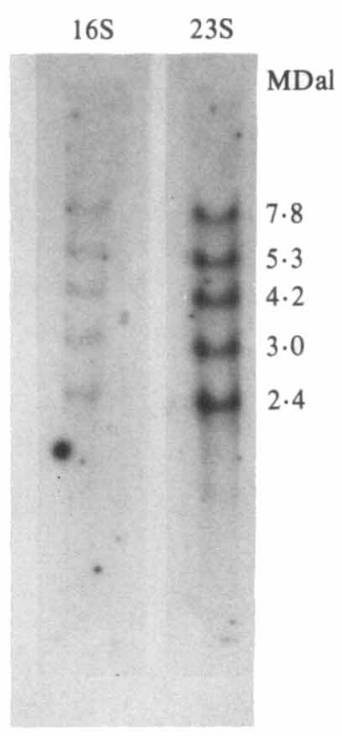

(a)

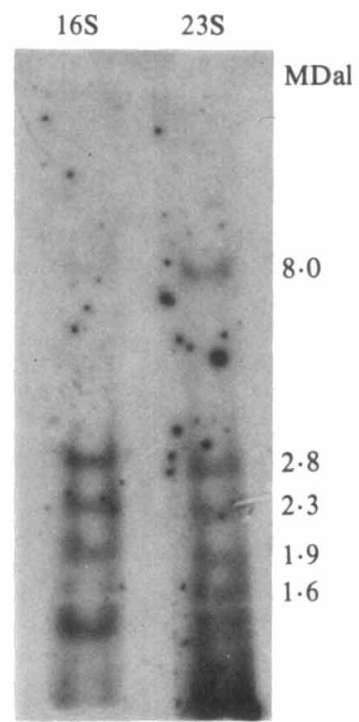

(b)

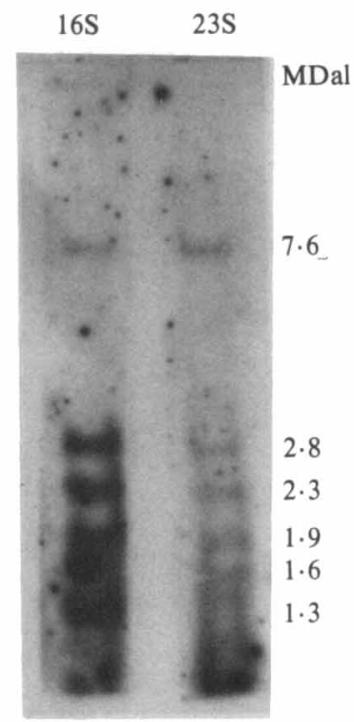

(c)

Fig. 2. Hybridization of ${ }^{32} \mathrm{P}$-labelled rRNAs to Anabaena CA DNA resolved on $0.7 \%$ agarose gels. The DNA was digested with $(a)$ EcoRI or $(b, c)$ HindIII, and following transfer to nitrocellulose filter strips was hybridized with: (a) Anabaena CA $16 \mathrm{~S}$ rRNA (1.6 × $10^{5}$ c.p.m., $\left.210 \mathrm{ng}\right)$ or Anabaena CA $23 \mathrm{~S}$ rRNA $\left(1.6 \times 10^{5}\right.$ c.p.m., $\left.70 \mathrm{ng}\right) ;(b)$ Anabaena CA 16S rRNA $\left(3.9 \times 10^{5}\right.$ c.p.m., $\left.540 \mathrm{ng}\right)$ or Anabaena CA 23S rRNA $\left(3.7 \times 10^{5}\right.$ c.p.m., $\left.270 \mathrm{ng}\right) ;\left(\right.$ c) Anabaena cylindrica $16 \mathrm{~S}$ rRNA $\left(5 \times 10^{5}\right.$ c.p.m., $\left.30 \mathrm{ng}\right)$ or Anabaena cylindrica $23 \mathrm{~S}$ rRNA $\left(5 \times 10^{5}\right.$ c.p.m., $\left.30 \mathrm{ng}\right)$. The sizes of the DNA fragments are given in MDal.

fragments that hybridize with the $16 \mathrm{~S}$ and $23 \mathrm{~S}$ rRNAs. These were not evident but it is possible that they had not been retained on the cellulose nitrate filter during the stringent washing procedure. However, these results confirm those obtained with Anabaena CA DNA digested with $E c o$ RI, in that they show a minimum of five rRNA cistrons.

Hybridization of rRNAs from Anabaena cylindrica to HindIII-digested Anabaena CA DNA gave the same signals as for the rRNA from Anabaena CA (Fig. $2 c$ ). This demonstrates the high degree of conservation between the rRNA of these two species of cyanobacteria.

\section{Anabaena cylindrica and Nostoc MAC}

The hybridization of rRNAs from Anabaena cylindrica to DNA digested with EcoRI again showed that $16 \mathrm{~S}$ and $23 \mathrm{~S}$ rRNA cistrons are closely linked, since, excepting two that were faintly labelled, they hybridized to identical DNA fragments (Fig. $3 a$ ). The predominant bands are of molecular size 1.75 and $1.63 \mathrm{Mdal}$, pointing to minor heterogeneity within the rRNA cistrons. No good explanation can be found for the less intensely labelled fragments of both higher and lower molecular weights. The $2.85 \mathrm{MDal}$ fragment only hybridized to $16 \mathrm{~S}$ rRNA, as did the (probable) double fragment of approximately 0.55 MDal. Degradation of the DNA could explain the presence of smaller fragments, although it is unlikely that one would be able to detect well-defined labelled fragments resulting from this process. Incomplete digestion may explain the larger fragments; however, the experiment was repeated a number of times, with the same results.

The hybridization pattern obtained when $A$. cylindrica DNA was digested with HindIII is shown in Fig. 3(b). Both $16 \mathrm{~S}$ and $23 \mathrm{~S}$ rRNAs hybridized to six identical fragments of 4.95, 3.95, $2 \cdot 50,2 \cdot 27,1.80$ and $1.28 \mathrm{MDal}$. This result suggested a minimum of six rRNA cistrons for $A$. cylindrica. Ribosomal RNAs from Nostoc MAC hybridized to DNA digested with EcoRI gave identical hybridization signals, although these signals were not of the same relative intensity 


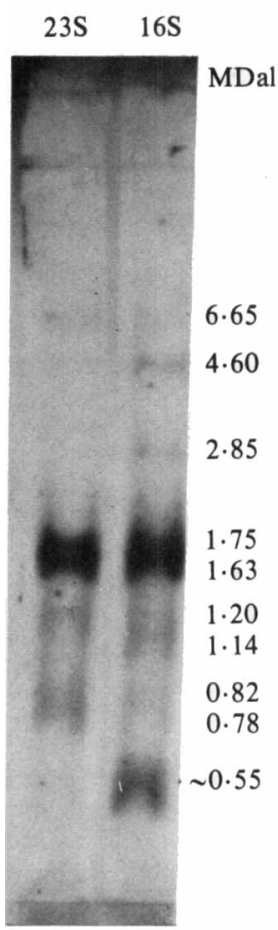

(a)

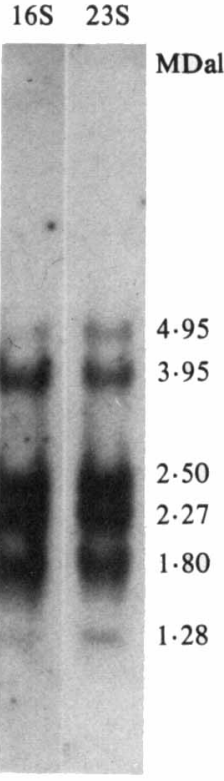

(b)

Fig. 3

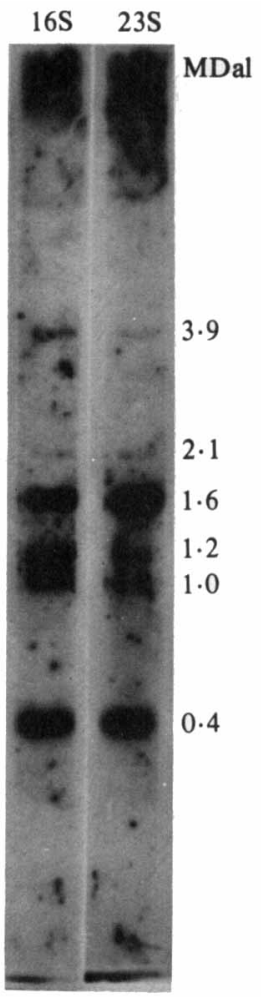

Fig. 4

Fig. 3. Hybridization of ${ }^{32}$ P-labelled Anabaena cylindrica rRNAs to $A$. cylindrica DNA. The DNA was digested with (a) EcoRI or (b) HindIII, resolved on $0.7 \%$ agarose gels, and following transfer to nitrocellulose strips was hybridized with: (a) $23 \mathrm{~S}$ rRNA $\left(10^{6}\right.$ c.p.m., $\left.800 \mathrm{ng}\right)$ or $16 \mathrm{~S}$ rRNA (106 c.p.m., $685 \mathrm{ng})$; (b) 16S rRNA $\left(1.5 \times 10^{6}\right.$ c.p.m., $\left.100 \mathrm{ng}\right)$ or $23 \mathrm{~S}$ rRNA $\left(1.5 \times 10^{6}\right.$ c.p.m., $\left.94 \mathrm{ng}\right)$. The sizes of the DNA fragments are given in MDal.

Fig. 4. Hybridization of ${ }^{32}$ P-labelled Nostoc MAC rRNAs to Nostoc MAC DNA. The DNA was digested with $E c o$ RI, resolved on a $0.7 \%$ agarose gel, and following transfer to nitrocellulose filter strips was hybridized with $16 \mathrm{~S}$ rRNA $\left(10^{6}\right.$ c.p.m., $\left.310 \mathrm{ng}\right)$ or $23 \mathrm{~S}$ rRNA $\left(10^{6}\right.$ c.p.m., $\left.218 \mathrm{ng}\right)$. The molecular sizes of the DNA fragments are given in MDal.

(Fig. 4). The most intensely labelled fragments were 1.6 and $0.4 \mathrm{MDal}$, with additional labelled fragments of $1 \cdot 0,1 \cdot 2,2 \cdot 1$ and 3.9 MDal. Again, the results indicate that the 16S rRNA and 23S rRNA cistrons are closely linked. The generation of the fragments of molecular size $2 \cdot 1 \mathrm{MDal}$ and less, hybridizing to both $16 \mathrm{~S}$ and $23 \mathrm{~S}$ rRNAs must be the result of two EcoRI sites within the rRNA cistrons, and also suggests the presence of multiple cistrons. As with the results from Anabaena cylindrica, it is unlikely that degradation or incomplete restriction of the DNA explains the multiple bands.

\section{DISCUSSION}

In the four species of cyanobacteria studied, the cistrons for 16S rRNA and 23S rRNA are closely linked. This is in agreement with the arrangements found in other prokaryotes such as Escherichia coli (Kiss et al., 1977; Lund et al., 1976), Bacillus subtilis (Zingales \& Colli, 1977), Bacillus thuringiensis (Klier et al., 1979) and Beneckea harveyi (Lamfrom et al., 1978). In addition, the results also demonstrate the diversity of the cyanobacteria with respect to the number of rRNA cistrons. In Anacystis nidulans there are probably only two cistrons, whereas in Anabaena 
CA there appears to be a minimum of five. Anabaena cylindrica and Nostoc MAC both gave complicated hybridization patterns with EcoRI-digested DNA, suggesting the presence of multiple rRNA cistrons, although the exact number could not be determined. The hybridization of $A$. cylindrica rRNAs with HindIII-digested DNA indicated the presence of at least six cistrons.

Although the position of the $5 \mathrm{~S}$ rRNA cistron in relation to the $16 \mathrm{~S}$ and $23 \mathrm{~S}$ rRNA cistrons was not unequivocally determined, preliminary experiments with $A$. cylindrica and Nostoc MAC suggested that they were closely linked, since 5S rRNA hybridized to the same DNA fragments as the $16 \mathrm{~S}$ and $23 \mathrm{~S}$ rRNAs. Results obtained for Anabaena CA and A. cylindrica cannot be adequately interpreted without the assumption that there is minor heterogeneity within the rRNA cistrons themselves. Indeed, this was found to be the case in Bacillus thuringiensis (Klier et al., 1979). It has been demonstrated that the rRNA genes in Beneckea harveyi are linked in a different order to that in other prokaryotes (Lamfrom et al., 1978), therefore the transcriptional organization of rRNA genes in cyanobacteria should be investigated, since it is of evolutionary importance (Doolittle, 1979).

Renaturation kinetics give an average mean value for genome size of $2.21 \times 10^{9} \mathrm{Dal}$ for the unicellular, non-nitrogen fixing type of cyanobacteria exemplified by $A$. nidulans and a value of $3.56 \times 10^{9} \mathrm{Dal}$ for heterocyst-forming, nitrogen-fixing species, such as the two Anabaena species used in this work (Herdman et al., 1979). Assuming that the increase in genome size had been by a process of gene evolution involving a series of fusions of a smaller ancestral genome (Herdman et al., 1979) and there had been no mutational alteration in the flanking sequences between the ribosomal RNA cistrons, the mapping of rRNA genes on to endonuclease-digested DNA would be identical with respect to location and number of sites in the cyanobacteria containing the small and larger genomes. However, if, as one would expect from the significant differences between the different groups of cyanobacteria, extensive mutation had occurred, giving rise to new restriction sites, then a more complex arrangement of rRNA genes would be presented. This appears to be the case, although it should be noted that the increase in ribosomal RNA cistrons from two to five does not exactly coincide with the measured increase in the genome size itself.

Cyanobacteria, like other prokaryotes, have increased amounts of RNA per cell in rapidly, relative to slowly, growing exponential cultures (Mann \& Carr, 1974). However, greater differences in RNA content per cell are revealed in a comparison between species, and these no doubt reflect the considerable divergence in cell volume. Thus $A$. nidulans has an RNA content of $20 \times 10^{-14} \mathrm{~g}$ per cell (Mann \& Carr, 1974) as compared with $300 \times 10^{-14} \mathrm{~g}$ per cell in $A$. cylindrica (Simon, 1977; J. M. Nichols \& N. G. Carr, unpublished observations), each value being derived from cultures growing at about half maximum growth rate. Even taking into account the fact that the growth rate of the latter organism was approximately four times slower, it is clear that a larger number of gene sites would be necessary to synthesize the requisite amount of rRNA. It may, therefore, be reasonable to interpret the increased number of rRNA cistrons in Anabaena species relative to A. nidulans in terms of a gene dosage effect.

This study was supported by a grant from the Science and Engineering Research Council. We are grateful to Dr D. G. Adams for helpful discussions.

\section{REFERENCES}

Allen, M. B. \& ARnon, D. I. (1955). Studies on nitrogen-fixing blue-green algae. I. Growth and nitrogen fixation by Anabaena cylindrica Lemm. Plant Physiology 30, 366-372.

Dobson, P. R., Doolittle, W. F. \& Sogin, M. L. (1974). Precursor of $5 S$ ribosomal ribonucleic acid in the blue-green alga Anacystis nidulans. Journal of Bacteriology 117, 660-666.
DoolitTLE, W. F. (1979). The cyanobacterial genome, its expression and the control of that expression. Advances in Microbial Physiology 20, 1-102.

Doolittle, W. F., Hofman, J. \& Sapienza, C. (1979). Analysis of transcription in Synechococcus 6301 using Southern hybridization. 3rd International Symposium on Photosynthetic Prokaryotes, Oxford. Edited by J. M. Nichols. p. E18. 
EXPert-Bezancon, A., Guerin, M-F., Hayes, D. H., Legault, L. \& Thibault, J. (1974). Preparation of E. coli ribosomal subunits without loss of biological activity. Biochimie 56, 77-89.

FRANKLIN, R. M. (1966). Purification and properties of the replicative intermediate of the RNA bacteriophage R17. Proceedings of the National Academy of Sciences of the United States of America 55, 1504 1511.

Hamkalo, B. A. \& Miller, O. L. JR (1973). Visualization of genetic transcription. In Gene Expression and its Regulation, pp. 63-74. Edited by F. T. Kenney, B. A. Hamkalo, G. Favelukes \& J. T. August. New York: Plenum Press.

Hassur, S. M. \& Whitlock, H. W. JR (1974). UV shadowing - a new and convenient method for the location of ultraviolet absorbing species in polyacrylamide gels. Analytical Biochemistry 59, 162-164.

Herdman, M., JaNVIER, M., RipPKa, R. \& Stanier, R. Y. (1979). Genome size of cyanobacteria. Journal of General Microbiology 111, 73-85.

Kenerley, M. E., Morgan, E. A., Post, L., Lindahl, L. \& NOMURA, M. (1977). Characterization of hybrid plasmids carrying individual ribosomal ribonucleic acid transcription units of Escherichia coli. Journal of Bacteriology 132, 931-949.

Kiss, A., Sain, B. \& Venetianer, P. (1977). The number of rRNA genes in Escherichia coli. FEBS Letters 79, 77-79.

KLIER, A. F., KUnST, F. \& RAPPORT, G. (1979). Structure of cloned ribosomal DNA cistrons from Bacillus thuringiensis. Nucleic Acids Research 7, 997 1010.

Kratz, W. A. \& MYers, J. (1955). Nutrition and growth of several blue-green algae. American Journal of Botany 42, 282-287.

Lamfrom, H., Sarabhai, A. \& Abelson, J. (1978). Cloning of Beneckea genes in Escherichia coli. Journal of Bacteriology 133, 354-363.

LoENING, U. L. (1968). Molecular weights of ribosomal RNA in relation to evolution. Journal of Molecular Biology 38, 355-365.

LuND, E., DAHLBERG, J. E., LiNDAHL, L., JASKunas, S. R., DenNIS, P. P. \& Nomura, M. (1976). Transfer RNA genes between $16 \mathrm{~S}$ and 23S rRNA genes in
rRNA transcription units of Escherichia coli. Cell 7, 165-177.

ManN, N. \& CARR, N. G. (1974). Control of macromolecular composition and cell division in the bluegreen alga Anacystis nidulans. Journal of General Microbiology 83, 399-405.

MARMUR, J. (1961). A procedure for the isolation of deoxyribonucleic acid from micro-organisms. Journal of Molecular Biology 3, 208-218.

MAXAM, A. M. \& GilberT, W. (1977). A new method for sequencing DNA. Proceedings of the National Academy of Sciences of the United States of America 74, 560-564.

PACE, N. (1973). Structure and synthesis of the ribosomal ribonucleic acid of prokaryotes. Bacteriological Reviews 37, 562-603.

Potter, S. S., BotT, K. F. \& Newbold, J. E. (1977). Two-dimensional restriction analysis of the Bacillus subtilis genome: gene purification and ribosomal ribonucleic acid gene organization. Journal of Bacteriology 129, 492-500.

RipPKa, R., Deruelles, J., Waterbury, J. B., Herdman, M. \& Stanier, R. Y. (1979). Generic assignments, strain histories and properties of pure cultures of cyanobacteria. Journal of General Microbiology 111, 1-61.

Silberklang, M., Gillum, A. M. \& Rajbhandary, U. L. (1979). Use of in vitro ${ }^{32}$ P-labelling in the sequence analysis of non-radioactive tRNAs. Methods in Enzymology 59, 58-109.

SimON, R. D. (1977). Macromolecular composition of spores from the filamentous cyanobacterium Anabaena cylindrica. Journal of Bacteriology 129, 1154-1155.

Southern, E. M. (1975). Detection of specific sequences among DNA fragments separated by gel electrophoresis. Journal of Molecular Biology 98, 503-517.

Stanier, R. Y. \& Cohen-Bazire, G. (1977). Phototrophic prokaryotes: the cyanobacteria. Annual Review of Microbiology 31, 225-274.

Zingales, B. \& Colli, W. (1977). Ribosomal RNA genes in Bacillus subtilis. Evidence for a cotranscriptional mechanism. Biochimica et biophysica acta 474, 562-577. 